\title{
The Relationship Between Price And Volume For The Russian Trading System
}

Carl B. McGowan, Jr., Norfolk State University, USA Junaina Muhammad, Universiti Putra, Malaysia

\begin{abstract}
The objective of this study is to analyze the relationship between the Russian Trading System Index and trading volume for the Russian Trading System Index. We use daily closing price and trading volume for the data for the RTS Index from September 4, 1995 to November 8, 2011. We find a positive statistically significant relationship between the natural logarithm of price volume changes and changes in the RTS Index and for the natural logarithm of price volume changes relative to a five-day average of price volume changes; thus the impact of trading volume is persistent.
\end{abstract}

Keywords: The Stock Price Trading Volume Relationship; Market Efficiency; Russian Trading System

\section{INTRODUCTION}

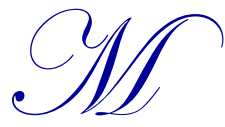

cGowan (2011) analyzes weak form market efficiency for the Russian Trading System Index for the period 1995 to 2007 using runs tests and serial correlation tests and finds that during the later period, after 2000, the RTSI follows a random walk and does not exhibit serial correlation. However, the probability distributions of returns for the RTSI are not normally distributed for the test period. McGowan and Ibrahim (2009) examine the day-of-the-week effect for the RTSI for the period 1995 to August 2003 using ARCH/GARCH analysis and find that changes in the RTSI are persistent. A positive (negative) return one day implies a positive (negative) return the following day. The RTSI exhibits a weekend effect, but for three days from Thursday to Monday.

The objective of this study is to determine if trading volume has an impact on changes in the RTSI and vice versa. We analyze returns and trading volume from September 1, 1995, when the RTS opened until June 1, 2007, for a total of 2,933 daily observations. We regress the change in the RTSI against the natural logarithm for the same day, the natural logarithm of the change in trading volume, and the natural logarithm of the change in trading volume divided by the five-day leading average of the natural logarithm of the change in trading volume.

\section{LITERATURE REVIEW}

Smirlock and Starks (1988) investigate the relationship between absolute stock price changes and trading volume in the stock market. Moosa and Silvapulle (2001) examine the relationship between the natural logarithm of futures prices and the natural logarithm of trading volume. Silvapulle and Choi (1999) study the relationship between the ratio of short interest to total outstanding shares in the stock market and the price-volume relationship. Assogbavi, Khoury and Yourougou (1995) evaluate the relationship between trading volume and absolute price changes and unadjusted price changes and trading volume. Moosa and Loughani (1995) and Saatcioglu and Starks (1998) examine the relationship between trading volume and price changes. Other studies focus on causality between daily stock returns and trading volume such as Chen and Liau (2004) and Moosa and Loughani (1995).

Moosa and Loughani (1995) argue that price movements are accompanied by increase in trading volume and that trading volume is greater (less) during bull (bear) markets. Empirical results support the idea of a positive relationship between trading volume and price changes. However, causality is not unidirectional and may, in fact, be bidirectional. We address this issue in the current research. 
Ying (1966), discussed in Ramasamy and Shanmugam (2003), suggests that the relationship between trading volume and price changes is asymmetric. Ying investigates whether the sign of price changes or the absolute value of price changes is the correct price measure to use to investigate the empirical relationship. Ying (1966) argues that an asymmetric relationship exists between trading volume and price changes and the signed price change is the correct measure. Smirlock and Starks (1988) measure the relationship using absolute value of the stock price changes and the absolute value of trading volume. Smirlock and Starks' empirical results support the hypothesis that the absolute value of price changes Granger Cause trading volume companies and that the relationship is stronger during periods surrounding earnings announcements.

Price-volume relationship can be defined as a relationship if changes in prices are related to changes in trading volume. Ord (2009) shows that share price and trading volume react to previous highs and lows and that price pushes through or reverses at points where volume changes. In general, there is a positive relationship between trading volume and price changes in financial markets. This positive relationship is supported with theory and empirical evidence.

On the theoretical study, the existence of this positive relationship can be explained by the Sequential Information Flow Model (SIF) of Copeland (1976) or the Mixture of Distribution Hypothesis (MDH) of Clark (1973). While in an empirical study, Karpoff (1987) reviews earlier studies in the literature and reports that, in general, the evidence is in favor of a positive relationship between price changes and volume. There are other empirical studies, such as Clark (1973) and Crouch (1970), that report a positive contemporaneous relationship between absolute returns and aggregate volume in different markets.

Furthermore, there is evidence of stock price changes leading trading volume on selected emerging markets by Assogbavi and Osagie (2006). To support this positive relationship between the absolute value of stock price changes and volume, transactions level, hourly, daily, weekly, and monthly data on individual stocks, futures, and stock price indices have been used in the previous empirical work.

Generally, rising volume is a trend continuation indicator and falling volume is the end of a trend or a reversal indicator. Those indicators help day traders to adopt an appropriate trading strategy indicating whether to buy or sell the stocks (Jen, 2003). There are two well-publicized adages in the financial market that always linked to the study of price-volume relationship (Walter, 2003; Karpoff, 1987; Epps, 1975). First, investors generally believe that volume is heavy in bull markets and light in bear markets. Secondly, investors presume that volume causes price movements. If both adages are correct, then understanding this relation is important.

Furthermore, stock prices and volume are joint products from one single market structure and if the prices and volume are separate, then any model of the stock market will inevitably either generate incomplete or erroneous results (Ying, 1966). Besides, more can be learned about the market by studying the joint dynamics of prices and trading volume rather than by focusing on the prices dynamics only as asserted by Gallant et al. (1992).

Osborne (1959) attempted to model stock price changes as a proliferation process with variance dependent on the number of transactions, which supports the hypothesis of a positive relationship between volume and the absolute value of price change. Furthermore, there are empirical studies that support this positive relationship, such as Clark (1973) and Crouch (1970). Moreover, Karpoff's (1987) examines and summarize findings of studies of the price-volume relationship. His main conclusions support the positive relationship between volume and price change.

This price-volume relationship has been studied from a variety of perspectives. For example, an early empirical investigation of the price-volume relationship was conducted by Granger and Morgenstern (1963), who examined the relationship between price indices and aggregate exchange volume, but they do not find a relationship between price indices and aggregate exchange volume. However, another finding by Godfrey, Granger, and Morgenstern (1964) is that there has positive relationship between daily volume and difference between the daily high and daily low.

Furthermore, Ying (1966) have concluded that: 
- $\quad$ a small volume is normally accompanied by a decrease in price

- $\quad$ a large volume is normally accompanied by a increase in price

- a large increase in volume is normally accompanied by a large increase in price or a large decrease in price

The first two conclusions suggest that there is a positive relationship between volume and price change per se while the third conclusion supports the hypothesis of a positive relationship between volume and the absolute value of price change.

However, Epps (1975) and Copeland (1976) suggest the absolute value of price change and volume relationship is not linear. That is, positive price changes are associated with larger volume levels relative to the volume levels associated with negative price changes. In contrast, Crouch (1970) finds a positive relationship between volume and the magnitude of returns. Furthermore, Smirlock and Starks (1988) find a strong positive lagged relationship between volume and absolute price changes by using individual stock transaction data. Chan and Tse (1993) use the multiple time series approach of Tiao and Box (1981) and show that there is a positive correlation between price and volume through their residuals.

Previous studies that use price as a variable can be summarized as follow:

- $\quad$ The absolute price change (Clark,1973; Crouch, 1970; Godfrey, Granger \& Morgenstern, 1964; and Smirlock \& Starks, 1988)

- $\quad$ The price change per se (Epps \& Epps, 1976; Granger and Morgensterm, 1963; Rogalski, 1978; and Ying, 1966)

- $\quad$ The variance of price changes (Epps \& Epps, 1976)

- $\quad$ Squared price changes (Clark, 1973)

There are many studies of the price-volume relationship in the stock market. For example, Gallant, et al. (1992) investigate price and volume co-movement for the New York stock market and find that there is positive relationship between conditional volatility and volume and that large price movements are followed by high volume. Similar empirical results have been found in the Taiwan stock market (Huang and Yang, 2001), the Russian stock market (Assogbavi, Schell and Fagnissè, 2007), and major Latin-American stock markets (A. Christofi and A. Pericli, 1999). Girard and Mohammed (2009) find a similar relationship between trading volume and stock price volatility in the Cairo and Alexandria Stock Exchange (CASE).

Thanh and Surendranath (2008) investigate the trading volume and stock return relationship in different international stock markets and find that the relationship is asymmetric among markets and stronger in less developed markets. Al-Deehani (2007) investigates the asymmetric price-volume relationship in nine stock markets and finds the existence of an asymmetric effect and that higher volume is associated more with price increase rather than with price decrease. Many studies provide evidence of the price-volume relationship in stock markets in the option market. Long (2007) finds that positive price changes are associated with significantly higher volume levels than negative price change.

The Granger causality method (Granger, 1969) has been used to investigate the relationship between volume and price and to investigate the presence of causality between stock returns and trading volume. Hiemsta and Jones (1995) find a significant positive, bi-directional relationship between stock returns and trading volume using non-linear Granger causality and a unidirectional relationship between stock returns and trading volume using a linear Granger model. Wang (1994) finds that the relationship between trading volume and stock returns is affected when trading is informational or non-informational (noise).

Further evidence using the Granger causality method has been found in USA, Japan, UK, France, Italy, Switzerland, Netherland, Hong Kong, Chile, and Canada by using national stock indices, strong Granger causality from returns to volume, and weaker Granger causality from volume to returns have been found. Moosa and AlLoughani (1995) find strong evidence for causality running from volume to absolute price changes and from price changes to volume in all markets, except the Philippines, in tests in four Asian stock markets. 
Kamath and Wang (2006) examine the price-volume relationship in six Asian equity markets from January 2003 to October 2005. The results of the Granger causality tests indicate an absence of causality in either direction in four of the six markets. The authors report evidence of causality running from stock returns to trading volume in the South Korean market and inverse causality in the Taiwanese market. Kamath (2008) investigates the Chilean stock market and finds a statistically significant contemporaneous relation between trading volume and stock returns in the Chilean stock market. The evidence indicates that the relationship is asymmetric and the causality results provide support for the hypothesis that daily stock returns Granger cause daily trading volume changes in the Chilean equity market.

Other studies that employed the Granger causality method to investigate the price-volume relationship are done by Chen and Liao, 2003; Ravindra, 2007; Abdul, 2007; Silvapulle and Choi, 1999; Kamath, 2008; and Deo et $a l ., 2008$. These findings support the significant relationship between price and volume.

On the other hand, the theoretical models that suggest a positive relationship between trading volume and the absolute value of price changes is called the Sequential Information Flow Model (SIF) of Copeland (1976), the Mixture of Distributions Hypothesis (MDH) of Clark (1973), and the Life-cycle Trading Hypothesis (LTH), Rational Expectation Asset Pricing (REAP), and Differences of Opinion (DO model).

The Sequential Information Flow (SIF) is a model in which information is disseminated to only one trader at a time. It allows for intermediate informational equilibrium and implies a positive relationship between volume and the absolute value of price changes. Hiemstra and Jones (1994) argue that a SIF results in lagged volume, which forecasts current volume, while the MDH implies only a positive contemporaneous causality from trading volume to absolute price changes with no inter-temporal causality in either direction. Mixture of Distributions Hypothesis $(\mathrm{MDH})$ is considered a special distribution of speculative prices and information dissemination is contemporaneous.

Clark (1973) and Epps and Epps (1976) provide theoretical support for the hypothesis that the variance of prices is a function of transaction volume. Epps and Epps (1976, page 305) suggest that price changes can be "viewed following a mixture of distributions, with transaction volume as the mixing variable." Karpoff (1987) argues that MDH is consistent with the empirical distribution of price changes.

\section{RTSI METHODOLOGY}

The Russian Trading System Index (RTSI) is a capitalization, weighted index with free-floating coefficients. The discussion of the RTSI is taken from Index Description, http://www.rts.ru/en/index/RTSIDescription.aspx, List of Stocks, http://www.rts.ru/s620, and Rules of Forming the List of Securities - Constituents of the RTS Index, http://www.rts.ru/s692. The opening value is the first RTSI value calculated on the day and the closing value is the last index value calculated on the day. The initial value of the RTSI, $I_{1}$ on September 1, 1995 was 100 and the closing value on November 8, 2011, $\mathrm{I}_{4237}$, was 1579.82 . The value of the RTSI on any day is calculated as

$\mathrm{I}_{\mathrm{t}}=\mathrm{Zn} * \mathrm{I}_{\mathrm{t}-1}\left(\mathrm{MC}_{\mathrm{t}} / \mathrm{MC}_{\mathrm{t}-1}\right)$

where $Z_{n}$ is the correcting coefficient, $M_{n}$ is the sum of the stock market capitalization measured in US dollars on day $\mathrm{n}$, and $\mathrm{MC}_{1}$ is the market capitalization measured in US dollars on day 1 - September 1, 1995.

$\mathrm{MC}_{\mathrm{n}}=\Sigma \mathrm{W}_{\mathrm{i}} *\left(\mathrm{P}_{\mathrm{ti}}\right)\left(\mathrm{Q}_{\mathrm{i}}\right) * \mathrm{C}_{\mathrm{i}}$

where $\mathrm{W}_{\mathrm{i}}$ is the coefficient to correct for free-float of the $\mathrm{i}^{\text {th }}$ security, $\mathrm{Q}_{\mathrm{i}}$ is the number of shares of the $\mathrm{i}^{\text {th }}$ security issued as of the current date, $\mathrm{Pi}$ is the price of the $\mathrm{i}^{\text {th }}$ security in US dollars at the time the $\mathrm{MC}_{\mathrm{n}}$ is measured, and ' $\mathrm{n}$ ' is the number of stocks in the RTSI. 


\section{RESEARCH DESIGN}

To examine the relationship between the daily changes in the value of RTSI and trading volume, we conduct five regressions. Model 1 is the regression between changes in the RTSI and the natural logarithm of contemporaneous volume, $\ln \left(\mathrm{V}_{0}\right)$.

$\operatorname{RTSI}_{\mathrm{t}}=\mathrm{a}+\mathrm{b}\left(\ln \left(\mathrm{V}_{0}\right)\right)+\mathrm{e}$

Model 1

where

RTSIt $=$ the change in the RTSI for the current day

$\operatorname{Ln}()=$ the natural logarithm operator

$\mathrm{V}_{0}=$ the trading volume for the current day

$\mathrm{V}_{-1}=$ the trading volume for the previous day

$\mathrm{e}=$ the residual

Model 1 tests to determine if the relationship between stock price changes and daily trading volume are contemporaneous.

Model 2 is the regression between changes in the RTSI and the natural logarithm of volume from the previous day, $\ln \left(\mathrm{V}_{-1}\right)$.

$\operatorname{RTSI}_{\mathrm{t}}=\mathrm{a}+\mathrm{b}\left(\ln \left(\mathrm{V}_{-1}\right)\right)+\mathrm{e}$

Model 2

Model 2 tests to determine if the relationship between stock price changes and daily trading volume is such that the stock price changes lag the trading volume.

Model 3 is the regression between changes in the RTSI and the natural logarithm of changes in trading volume, $\ln \left(\mathrm{V}_{0} / \mathrm{V}_{-1}\right)$.

$\operatorname{RTSI}_{\mathrm{t}}=\mathrm{a}+\mathrm{b}\left(\ln \left(\mathrm{V}_{0} / \mathrm{V}_{-1}\right)\right)+\mathrm{e}$

Model 3

Model 3 tests the relationship between stock price changes and the natural logarithm of changes in the trading volume between the current day and the previous day. This model will tell if the actual level of trading volume or the change in trading volume affect stock prices.

Model 4 is the regression between changes in the RTSI and the natural logarithm of contemporaneous trading volume divided by the average of the previous five-days trading volume, $\ln \left(\mathrm{V}_{0}\right) /\left(\right.$ average $\left(\ln \left(\mathrm{V}_{-1}\right)\right.$ to $\left.\ln \left(\mathrm{V}_{-5}\right)\right)$ ).

$\operatorname{RTSI}_{\mathrm{t}}=\mathrm{a}+\mathrm{b}\left(\ln \left(\mathrm{V}_{0} / \mathrm{V}_{-1}\right) / \mathrm{avg}\right)+\mathrm{e}$

Model 4

$\operatorname{Avg}=$ the average of volume for the five previous days.

Model 4 tests to determine if the change in trading volume relative to the average of the daily change in trading volume for the previous five days affects stock prices. Model 4 determines if relative changes in trading volume affect stock price changes.

Model 5 is the regression between changes in the RTSI and the natural logarithm of contemporaneous trading volume divided by the average of the previous five days trading volume lagged for one period.

$\operatorname{RTSI}_{\mathrm{t}}=\mathrm{a}+\mathrm{b} \operatorname{lagged}\left(\left(\ln \left(\mathrm{V}_{0} / \mathrm{V}_{-1}\right) / \mathrm{avg}\right)\right)+\mathrm{e}$

Model 5

Model 5 lags the change in trading volume adjusted for the previous five-day average in the change in trading volume. 
Each of the five models is run as a separate regression. The empirical results will indicate which particular pattern of trading volume has more explanatory power in explaining stock price changes.

\section{EMPIRICAL RESULTS}

Table 1 presents the empirical results for the five models used to test the relationship between trading volume and returns for the Russian Trading System Index. Model 1 examines the relationship between changes in the RTSI and the natural logarithm of contemporaneous trading volume. The regression coefficient is small and is not statistically significant. The F-statistic for the overall regression is not statistically significant and the adjusted $\mathrm{R}^{2}$ is small. Model 2 examines the relationship between changes in the RTSI and the natural logarithm of the previous day's trading volume. The regression coefficient is small and negative and is not statistically significant. The F-statistic for the overall regression is not statistically significant and the adjusted $\mathrm{R}^{2}$ is small.

Table 1: Regression Coefficients

Russian Trading System Index Returns and Trading Volume

\begin{tabular}{|c|c|c|c|c|c|c|}
\hline Model & Model & beta & T-stat & p-value & F & Adj R2 \\
\hline 1 & $\ln (\mathrm{V} 0)$ & 0.0004 & 1.3384 & 0.1808 & 1.7914 & 0.0002 \\
\hline 2 & $\ln (\mathrm{V}-1)$ & -0.0004 & -1.3522 & 0.1764 & 1.8286 & 0.0002 \\
\hline 3 & $\ln (\mathrm{V}-1 / \mathrm{V} 0)$ & 0.0061 & 7.4514 & 0.0000 & 55.5229 & 0.0133 \\
\hline 4 & $\ln (\mathrm{V}) / \mathrm{Avg}$ & 0.1331 & 9.5963 & 0.0000 & 92.0890 & 0.0221 \\
\hline 5 & $\ln (\mathrm{V}) / \mathrm{Avg}-1$ & 0.0274 & 1.9525 & 0.0509 & 3.8123 & 0.0007 \\
\hline
\end{tabular}

Model 3 provides the regression results between natural logarithm of the change in trading volume and the change in the RTSI. The beta coefficient is 0.0061 and is statistically significant at the 0.00 level of significance. The regression F-statistic is 55 and is statistically significant at the 0.0000 level. The adjusted $\mathrm{R}^{2}$ is 1.33 percent. Model 4 tests the relationship between changes in the RTSI and the natural logarithm contemporaneous trading volume divided by average of the five-day previous trading volume from $t=-1$ to $t=-5$. The beta coefficient is .1331 and is statistically significant and the F-stastic is 92 and statistically significant. The adjusted $\mathrm{R}^{2}$ is 0.00221 . Model 5 tests the relationship between changes in the RTSI and the lagged value of the natural logarithm contemporaneous trading volume divided by average of the five-day previous trading volume from $t=-1$ to $t=-5$. The beta coefficient is 0.0274 and is statistically significant at the 0.0509 level and the F-statistic is 3.81 and statistically significant at the 0.0509 level. The adjusted $R^{2}$ is 0.0007 .

\section{CONCLUSIONS}

In this study, we examine the relationship between changes in the Russian Trading System Index and five measures of trading volume and the natural logarithm of contemporaneous trading volume, the natural logarithm of the previous day's trading volume, the natural logarithm of change in trading volume, the natural logarithm of contemporaneous trading volume divided by the average trading volume for the previous five days, and the lagged devalue of the natural logarithm of contemporaneous trading volume divided by the average trading volume for the previous five days. We find that regressions of changes in the RTSI and the natural logarithm of changes in trading volume and changes in the adjusted trading volume are both statistically significant. These empirical results indicate that trading volume and changes in the RTSI are related and that the impact of volume changes on price changes is persistent.

\section{AUTHOR INFORMATION}

Carl B. McGowan, Jr., PhD, CFA is a Faculty Distinguished Professor and Professor of Finance at Norfolk State University, has a BA in International Relations (Syracuse), an MBA in Finance (Eastern Michigan), and a PhD in Business Administration (Finance) from Michigan State. From 2003 to 2004, he held the RHB Bank Distinguished Chair in Finance at the Universiti Kebangsaan Malaysia and has taught in Cost Rica, Malaysia, Moscow, Saudi Arabia, and The UAE. Professor McGowan has published in numerous journals including American Journal of Business Education, Applied Financial Economics, Decision Science, Financial Practice and Education, The 
Financial Review, International Business and Economics Research Journal, The International Review of Financial Analysis, The Journal of Applied Business Research, The Journal of Business Case Studies, The Journal of Diversity Management, The Journal of Real Estate Research, Managerial Finance, Managing Global Transitions, The Southwestern Economic Review, and Urban Studies. E-mail: cbmcgowan@nsu.edu (Corresponding author)

Junaina Muhammad holds a BS in Business Administration (Finance) and an MBA (Financial Management) from California State University, USA. She receives her Doctor of Business Administration (DBA) in Finance from University Kebangsaan Malaysia. Since 1998, Professor Junaina has been a full-time lecturer on the Faculty of Economics and Management at the University Putra Malaysia and teaches Finance, Islamic Finance, and Banking. Professor Junaina's research interests are Islamic Financial, Capital Market Management, Banking and Derivatives. Prof Junaina has published in Asia Pacific Journal of Finance and Banking Research, Business \& Economics Research Journal, Global Business and Finance Review, International Journal of Finance and Accountancy.

\section{REFERENCES}

1. Abdul. R, (2007). Stock prices and trading volume: An assessment for linear and nonlinear Granger causality. Journal of Asian Economics, 18 (2007) 595-612.

2. Al-Deehani, T. M., (2007). Modeling asymmetry in the price-volume relation: Evidence from nine stock markets. Investment Management and Financial Innovations, Volume 4, Issue 4, 2007.

3. Assogbavi, T., Khoury, N. and Yourougou, P. (1995). Short interest and the asymmetry of the price-volume relationship in the Canadian stock market. Journal of Banking and Finance, 19: 1341-1358.

4. Assogbavi, T. and J. Osagie. (2006). "Equity valuation process and price-volume relationship on emerging markets," International Business \& Economics Research Journal, volume 5, pp. 7-18.

5. Assogbavi, T., Schell, J., and Fagnissè,S., (2007). Equity price-volume relationship on the Russian Stock Exchange. International Business \& Economics Research Journal, September 2007, Volume 6, Number 9.

6. Chan, W.S., Tse, Y.K., 1993. Price-volume relation in stocks: a multiple time series analysis on the Singapore market. Asia Pacific Journal of Management, 10 (1), 39-56.

7. Chen, S.H. and Liao, C.C. (2004). Agent-based computational modeling of the stock price-volume relation. Information Sciences An International Journal, 1-26

8. Clark,P.K., (1973), A subordinated stochastic process model with finite variance for speculative prices. Econometrica, Vol. 41, No. 1. (January 1973), pp. 135-155.

9. Copeland, T. E. (1976). A model of asset trading under the assumption of sequential information arrival. Journal of Finance, 31, 1149- 1168.

10. A.Christofi and A.Pericli (1999), Correlation in price changes and volatility of major Latin American stock markets. Journal of Multinational Financial Management, 9 (1999) 79-93.

11. Crouch, R. L. (1970). The volume of transactions and price changes on the New York Stock Exchange. Financial Analysts Journal, 26, 104-109.

12. Deo, M., Srinivasan, K. and Devanadhen, K. (2008). The empirical relationship between stock returns, trading volume and volatility: Evidence from select Asia-Pacific stock market. European Journal of Economics, Finance and administrative Sciences, ISSN 1450-2275 Issue 12 (2008).

13. Epps, T. W. (1975).Security price changes and transaction volumes: Theory and evidence. The American Economic Review, Vol.65, No.4.

14. Epps, T. W., \& Epps, M. L. (1976). The stochastic dependence of security price changes and transaction volumes: Implications for the mixture-of-distributions hypothesis. Econometrica, 44, 305-321.

15. Gallant, A.R., Rossi, P.E., and Tauchen, G., (1992). Stock prices and volume. The Review of Financial Studies, Vol. 5, No. 2. (1992), pp. 199-242.

16. Godfrey, M.D., Granger, C.W.J., Morgenstern, O., (1964). The random-walk hypothesis of stock market behavior. Kyklos, 17 (1), 1-30.

17. Girard,E. and Mohammed,O., (2009). On the relationship between trading volume and stock price volatility in CASE. International Journal of Managerial Finance, Vol.5 No. 1, 2009.

18. Granger, C.W.J., (1969). Investigating causal relations by econometric models and cross-spectral methods. Econometrica, 37, 424-438.

19. Granger,C.W.J. and Morgenstern.O., (1963). Spectral analysis of New York stock market prices. Kyklos, $16(1), 1-27$. 
20. Hiemstra, C., Jones, J., (1994). Testing for linear and nonlinear Granger causality in the stock price-volume relation. Journal of Finance, XLIX, 1639-1664.

21. Huang, B.-N. and Yang C.-W. (2001), An empirical investigation of trading volume and return volatility of the Taiwan Stock Market. Global Finance Journal, 12 (2001) 55-77.

22. Jen, C. (2003). The day trader's link between price and volume, http://www.daytradingcoach.com/daytrading-articles-pricevolume.htm . Accessed on 2 September 2009.

23. Kamath, R. (2008). The price-volume relationship in the Chilean Stock Market. International Business and Economics Research Journal, Volume 7 number 10, p 7- 14.

24. Kamath R. and Y. Wang, "The Causality between Stock Index Returns and Volumes in the Asian Equity Markets," Journal of International Business Research, Vol.5, 2006, 63-74.

25. Karpoff, J.M., (1987). The relation between price changes and trading volume: a survey. Journal of Financial and Quantitative Analysis, 22 (1) (1987) 109-126.

26. Long,D.M., (2007),An examination of the price-volume relationship in the option markets. International Research Journal of Finance and Economics, ISSN 1450-2887 Issue 10 (2007).

27. McGowan, Carl B., Jr. "An Analysis of the Technical Efficiency of the Russian Stock Market," International Business \& Economics Research Journal, October 2011, Volume 10, Number 10, pp. 31-43.

28. McGowan, Carl B., Jr. and Izani Ibraham. "An Analysis of the Day-of-the-Week Effect in the Russian Stock Market," International Business \& Economics Research Journal, Volume 8, Number 9, September 2009, pp. 25-30.

29. Moosa, I.A. and Al-Loughani, E. (1995). Testing the price-volume relation in emerging Asian stock market. Journal of Asian Economics, 6(3): 407-422.

30. Moosa, I.A., and Silvapulle, P. (2000). The price-volume relationship in the crude oil futures market: some results based on linear and nonlinear causality testing. International Review of Economics and Finance, 9:11-30.

31. Ord,T. (2009).Combining Price and Volume to Predict Price Movement (Part 1), http://www.tradingmarkets.com/.site/stocks/how_to/articles/-76494.cfm.Accessed on 2 September 2009.

32. Osborne, M. (1959), Brownian motion in the stock prices. Operations Research, 7, 145-173.

33. Ramasamy, S. and Shanmugam, B. (2003). Price-volume causality: A study of the Malaysian stock index futures market. Proceedings of the Malaysian Finance Association Fifth Annual Symposium, April 23-24, Management Centre, Multimedia University Malaysia, 599 - 609.

34. Ravindra R.K., (2007). Investigating causal relations between price changes and trading volume changes in the Turkish Market. ASBBS E-Journal, Volume 3, No.1, 2007.

35. Rogalski, R. J. (1978). The dependence of prices and volume. Review of Economics and Statistics, 36, 268274.

36. RTSI Index Description, http://www.rts.ru/en/index/RTSIDescription.aspx

37. RTSI List of Stocks, http://www.rts.ru/s620

38. RTSI Rules of Forming the List of Securities - Constituents of the RTS Index, http://www.rts.ru/s692

39. Russian Stock Exchange web site, http://www.rts.ru

40. Saatcioglu, K. and Starks, L.T. (1998). The stock price-volume relationship in emerging stock markets: the case of Latin America. International Journal of Forecasting, 14: 215-225.

41. Silvapulle, P. and Choi, J.S. (1999). Testing for linear and nonlinear Granger causality in the stock pricevolume relation: Korean evidence. The Quarterly Review of Economics and Finance, 39(1): 59-76.

42. Smirlock, M. and Starks, L. (1988). An empirical analysis of the stock price-volume relationship. Journal of Banking and Finance, 12: 31-41.

43. Thanh, N. and Surendranath, R.J., (2008). International evidence on the relationship between trading volume and serial correlation in stock returns. Global Journal of Finance and Banking Issues, Vol. 2. No. 2. 2008.

44. Tiao, G C and G E P Box, (1981), Modeling multiple time series with applications, Journal of the American Statistical Association, 76, 802-816.

45. Walter, S. (2003). Relationship between Trading volume and security prices and returns. Area Exam Report, MIT Laboratory for Information and Decision Systems, Technical Report P-2638.

46. Wang, J., (1994). A model of competitive stock trading volume. Journal of Political Economy, 102, 127168.

47. Ying, C. C. (1966). Stock market prices and volume of sales. Econometrica, 34, 676-685. 